\title{
EDITORIAL: Edição internacional publicada
}

Vinculada ao Departamento de Pesquisa da Universidade Federal do Amapá, a revista Estação Científica (UNIFAP) apresenta a sua primeira edição publicada integralmente com artigos em inglês, sendo a maioria deles oriundos de autores do Irã, Rússia e Brasil. Esta abertura para além das fronteiras brasileiras representa um ponto importante ao assegurar a presença em contextos internacionais. Há muitos anos a revista tem atraído a atenção de pessoas de outros países, de pelo uns 60 países. Isto torna este periódico uma forma de divulgação de trabalhos científicos que tenham sido produzidos em qualquer região do planeta.

A presença de brasileiros em revistas nacionais é um ponto constante, que permite estabelecer a publicação de artigos com dados importantes, sejam estas pessoas autoras ou pareceristas. A prática de gestão de uma revista científica dá-se de forma coletivizada, sendo a editoria apenas o ponto de intermediação entre os que escrevem, os que avaliam e os que leem os textos. Os autores elaboram redações fundamentadas cientificamente, que são analisadas por especialistas convidados, os quais gentilmente colaboram com suas preciosas observações para a melhoria dos trabalhos dos autores. Após a publicação, os leitores têm acesso aos materiais aprovados, e a partir disto poderão utilizar as informações acessadas para os devidos fins, como complementar suas pesquisas e esclarecimentos e conhecimentos das descobertas.

Nesta direção seguem os artigos desta edição publicada: que sejam lidos e citados em publicações de outros autores, de tal forma que a ressonância científica seja sentida proativamente pela sociedade. As informações redigidas pelos autores desta edição internacional apresentam os dados científicos organizados para possibilitar a compreensão dos assuntos escolhidos e debatidos. Por isto que estamos sempre gratos ao labor escrito das pessoas-autoras, pois todas são audaciosas em realizar pesquisas teóricas e práticas e escolheram a revista Estação Científica (UNIFAP) para publicar os artigos dos seus trabalhos.

Conseguir a atenção de autores de outros países não é tarefa fácil, entretanto não é impossível. Da mesma forma como há brasileiros publicando em periódicos de outros países, a recíproca também acontece. O fato mais importante é estar-se disponível para esta abertura estrangeira, a qual acontece inicialmente com autores brasileiros publicando em outros idiomas, e em seguida vem a atração de autores estrangeiros, os quais são os principais divulgadores da revista em seus respectivos países.

Paralelo a isto, estamos trabalhando para possibilitar a tradução da interface da revista para o idioma inglês, haja vista facilitar o acesso das informações de praxe editorial a todos 
os interessados a este mecanismo de difusão do conhecimento. Há a pretensão futura de publicação de outras edições internacionais. A semente deste projeto está plantada faz algum tempo, sendo observada pela presença de artigos em língua inglesa nas edições que foram publicadas em 2017 e 2018. Desta forma, esta presente edição internacional simboliza o ápice do internacionalismo da revista Estação Científica (UNIFAP).

Boa leitura a todos/as.

Atenciosamente,

\section{Fernando Castro Amoras}

Editor-chefe da revista Estação Científica (UNIFAP) 